\title{
Methylphenidate, Bupropion, and SSRI Triple Therapy
}

\author{
William Bobo M.D. \\ National Capital Cosortium Military Psychiatry Residency - National Naval Medical Center, Walter Reed \\ Army Medical Center
}

Follow this and additional works at: https://jdc.jefferson.edu/jeffjpsychiatry

Part of the Psychiatry Commons

Let us know how access to this document benefits you

\section{Recommended Citation}

Bobo, William M.D. (2001) "Methylphenidate, Bupropion, and SSRI Triple Therapy," Jefferson Journal of Psychiatry. Vol. 16 : Iss. 1 , Article 8.

DOI: https://doi.org/10.29046/JJP.016.1.007

Available at: https://jdc.jefferson.edu/jeffjpsychiatry/vol16/iss1/8

This Article is brought to you for free and open access by the Jefferson Digital Commons. The Jefferson Digital Commons is a service of Thomas Jefferson University's Center for Teaching and Learning (CTL). The Commons is a showcase for Jefferson books and journals, peer-reviewed scholarly publications, unique historical collections from the University archives, and teaching tools. The Jefferson Digital Commons allows researchers and interested readers anywhere in the world to learn about and keep up to date with Jefferson scholarship. This article has been accepted for inclusion in Jefferson Journal of Psychiatry by an authorized administrator of the Jefferson Digital Commons. For more information, please contact: JeffersonDigitalCommons@jefferson.edu. 


\title{
Methylphenidate, Bupropion, and SSRI Triple Therapy
}

\author{
William Bobo, M.D. ${ }^{1}$
}

\begin{abstract}
Methylphenidate and bupropion have been demonstrated as being effective adjuncts to serotonin reuptake inhibitors in the treatment of depression $(1,2)$. The use of these medications in the form of triple therapy for cases of severe refractory illness has not been reported. We present the case of a depressed patient whose condition was resistant to several forms of monotherapy, monotherapy with "standard" augmentation and ECT. After only a partial response to fluoxetine and methylphenidate, bupropion was added, resulting in full, sustained remission.
\end{abstract}

\section{CASE REPORT}

BL is a middle aged male with dysthymia and severe recurrent major depression, and a negative past medical history. His illness had partially responded to fluoxetine, desipramine, phenelzine and paroxetine; however, his chronic low-grade depression and almost constant suicidal preoccupation never resolved. He received ECT, also with an initial good response, but later relapsed with a return of his episodic severe depression. Subsequent trials of bupropion with liothyronine augmentation, venlafaxine, and a combination of sertraline, nortriptyline and lithium all failed.

Since the initial fluoxetine trial was only two weeks time in length, it was restarted without significant improvement. Methylphenidate was thus added and titrated to a dose of $10 \mathrm{mg}$ bid. On this regimen, BL experienced improvement in energy level and demonstrated a brighter affect. Again, however, his low-grade depression and suicidal preoccupation continued. Bupropion, was then started and then titrated to a maximum dose of $100 \mathrm{mg}$ bid. The triple therapy was welltolerated, and brought about significant clinical improvement. His energy level improved further, and his dysphporia, sleep disturbance, anhedonia and suicidal ideation gradually resolved. At two-month follow-up, these improvements were sustained. Most importantly, his suicidal ideation remained markedly decreased. He continues to do well on this triple regimen of bupropion $100 \mathrm{mg}$ bid, fluoxetine 20 $\mathrm{mg}$, and methylphenidate $10 \mathrm{mg}$ bid, without significant side-effects.

This patient's experience suggests that in cases of severe depression that fails or

\footnotetext{
${ }^{1}$ William V. Bobo, M.D., LT, MC, USNR, Residency: National Capital Cosortium Military Psychiatry Residency (National Naval Medical Center, Walter Reed Army Med Ctr).
} 
partially responds to monotherapy, augmentation therapy and even EGT, the triple-therapy described may bring about clinical improvement. This patient's sustained response is rather encouraging, given his long history of severe and frequently recurrent illness. It is postulated that, via this regimen, levels of central serotonin, norepinephrine and dopamine may be more effectively increased, thereby exerting its added therapeutic benefit. It is also our opinion that this form of triple therapy represents an additional augmentation strategy which may be useful in cases like the one described, or when a combination of SRI and either methylphenidate or bupropion fails to bring about a full clinical response. Closer examination involving larger numbers of such patients is still needed in order to substantiate this position.

\section{REFERENCES}

1. Stoll AL, Pillay SS, Diamond L, et al: Methylphenidate augmentation of serotonin selective reuptake inhibitors: a case series. J Clin Psychiatry 1996; 57: 72-76.

2. Marshall RD, Johannet CM, Collins PY, et al: Bupropion and sertraline combination treatment in refractory depression. J Psychopharmacol 1995; 9: 284-286. 